\title{
Tourism and Biodiversity in North and South
}

Ralf Buckley, Director International Centre for Ecotourism Research, School of Environmental and Applied Sciences, Griffith University, Parklands Drive, Southport, Qld 4215, Australia. Phone: +61.7.55528675, Fax: +61.7.55528895,

Email: R.Buckley@mailbox.gu.edu.au

\section{Abstract}

Biodiversity in Southern nations is a significant attraction for Northern tourism: reefs and rainforests, whales and wildflowers, big game and biological rarities. It is therefore in the interests of international tourism to help conserve international biodiversity. The role of tourism in biodiversity conservation is especially significant in Southern nations because many Southern nations have particularly rich biodiversity but weak legal, land-use allocation, and development control systems, and protected area agencies with few funds and little political power. Northern tourism can provide incentives to conserve biodiversity through foreign exchange and economic opportunities for Southern governments and local communities. They can also buy private land for tourism and conservation, and lobby against logging and land clearance and other high-impact land uses. Northern tourism also relies on Northern biodiversity. Currently, tourism growth is a significant threat to many Northern protected areas. As a high-value use, tourism should displace primary industries in public and private lands of high biodiversity outside the protected area system, rather than inside parks. For political reasons, however, this rarely happens at present.

\section{Tourism in North and South}


The terms North and South, as a convenient shorthand to summarise differences in political and economic development history, are meaningful in the Americas and in the EuropeAfrican region, but less so in the Asia-Pacific region, where development histories defy separation into any simple geographic pattern. In the tourism context, the terms are perhaps most useful if North is applied to countries where the bulk of the population can afford to travel internationally, whereas in countries from the South, only a very small proportion of the population can afford international travel, or in many cases, any travel at all. Both Northern and Southern countries have both international and domestic tourism industries, but their relative economic significance is different.

There are a number of developing nations, however, with large areas and populations, substantial industrialisation, medium income overall and a significant proportion of the population who travel extensively within their own countries and to neighbouring nations. Examples include, India, China, Mexico, Brazil and Argentina. Similarly, there are developed countries such as South Africa, and increasingly also Australia and New Zealand, where the relatively low foreign exchange value of the local currency is restricting travel to Europe, North America and Japan for many residents. There is hence no clear classification of countries into North and South, developed and developing nations (Harrison 2001). All of these, however, are still useful criteria; and there are still far more Northern tourists with money, visiting Southern nations with interesting plants and animals, than the reverse.

\section{Biodiversity as a Tourist Attraction in North and South}

Biodiversity is a term from ecology rather than tourism. Technically, it refers to the diversity of living organisms at all scales. Commonly, three scales are considered: genetic, species and ecosystem. Species diversity refers to the total number (richness) and relative abundance (evenness) of individual species in the area concerned. Ecosystem diversity refers to the 
relationships between species, the ways they are combined into different assemblages, communities or ecosystems, and the variety of these ecosystems. Genetic diversity refers to genetic variation within species. Various mathematical indices have been devised to express biodiversity in quantitative terms.

Some components of biodiversity are significant tourist attractions. For mainstream tourism, the best-known biological attractions are large charismatic mammal species such as the "Big Five” in Africa, bears in Alaska, or whales in the world's coastal oceans. In many parts of the world, however, tourists also travel to see forests, wildflowers, birds, fish, coral and many other species. In reefs and rainforests, for example, it is the diversity of species rather than any single one which attracts tourists. The same applies in many other areas, such as the Galapagos Islands or Australia. Even where tourists may see tigers, wolves, polar bears, gorillas or cassowaries, tour guides and marketing materials emphasize the range of other species which form part of the experience. Even diversity at the genetic level can contribute to tourism. The various colour forms of giraffe and zebra in different parts of subsaharan Africa, for example, have different names and are treated as different tourist attractions, even though it appears that biologically they are part of the same species. Ecosystem-level biodiversity is also relevant, many scenic landscapes owe their character to vegetation as much as underlying geology.

Various components of biodiversity feature heavily in tourism marketing materials. In Africa and Latin America, individual species or overall species diversity are a major focus in tourism marketing. In Australia, Asia and USA it is a less obvious product component, but significant nonetheless. Biodiversity is a significant factor in a wide range of tourism product purchasing decisions. Obvious examples include: visits to zoos and wildlife reserves; wildlife watching, birdwatching, whalewatching and dive tours; and consumptive tourism such as 
hunting and fishing tours (Green and Higginbottom 2000). And in a much broader context, undisturbed ecosystems and their plant and animal communities are critical in maintaining the clean air, clean water and healthy environments which are a key tourism attraction in many destinations (Buckley 1999a).

Of course, there are also components of biodiversity which are of little or no interest to most tourists, such as worms, beetles, grasses and fungi. Other components may act as a definite deterrent, such as mosquitoes, stinging plants and insects, and pathogenic microorganisms. Even the smallest and least attractive of organisms, however, may play a vital role in maintaining the ecosystems that support the large animals that tourists come to see.

Biodiversity therefore provides a primary attraction and critical underpinning for a distinct subsector of the tourism industry, namely nature, eco and adventure tourism, NEAT (Buckley 2000a). It can also be a significant, though less critical component of other subsectors. As an approximation, therefore, the economic significance of biodiversity to the tourism industry can be estimated from the size of the NEAT sector.

This varies between countries (Buckley 1999a, 2000a). In countries such as New Zealand and Costa Rica, effectively the entire tourism industry is within the NEAT sector. In countries such as the USA, it appears that about half the tourism industry falls within the NEAT sector. In Australia, a supply-side estimate suggests that the NEAT sector makes up at least a quarter of the industry, and perhaps considerably more; and demand-side estimates indicate that the NEAT sector may comprise up to two thirds of the entire tourism industry (Buckley 2000a). Individual icon species in Australia can contribute \$1 billion or more to tourism turnover (Hundloe and Hamilton 1997). 
The Northern tourism industry relies heavily on Southern biodiversity. Both Northern and Southern tourism also rely on their own biodiversity, but Southern tourism does not rely on Northern biodiversity: the relationship is asymmetric. In tourism as in agriculture, forestry or pharmaceuticals, therefore, Southern biodiversity is traded for Northern cash. This is not necessarily either good or bad for either tourism or biodiversity, North or South: it depends on the terms of trade.

The tourism industry stands to lose far more than other industry sectors if biodiversity and natural environments are not adequately conserved. The two major industry sectors which depend most strongly on biodiversity are tourism and biotechnology. Whilst biotechnology companies gain access to genetic material from any part of the globe, however, tourism businesses need biodiversity in its native environment.

\section{Impacts of Tourism on Biodiversity}

Tourism can have both negative and positive impacts on biodiversity. Negative impacts are widespread and well-documented, and range from direct vegetation clearance and wildlife disturbance, to indirect effects such as accidental introduction of weeds and pathogens, or modifications to interactions between species (Buckley 1999a). Positive effects are potentially very significant but rarely demonstrated in practice. The most important is that by providing a source of revenue, tourism could assist in conserving natural environments against pressures for other, higher-impact land and water uses (Buckley 1999a). All these effects can occur in both North and South, but the relative significance of different effects and components, and the detailed mechanisms by which they act, differ between the two. 
The negative impacts of tourism on biodiversity may be considered at various different scales (Buckley 1999a, 2001a):

- impacts from travel by air, sea, rail and road, including those from air and water pollution and from airports, seaports, roads and railways

- impacts from urban tourism accommodation and associated facilities, power and water supply, materials consumption, and waste, wastewater and sewage discharge

- localized impacts on biodiversity from greenfields resorts and infrastructure

- localized on-ground impacts of general nature and adventure tours

- impacts of specialist tours to view individual icon species

- impacts of consumptive tourism, including hunting, fishing, shell collecting, and artefacts from plant or animal parts

- contribution of tourism to illegal trade in endangered plant and animal species

Northern tourists flying to Southern destinations make up a significant, contribution to international air travel and associated large-scale atmospheric impacts, including ozone depletion and greenhouse warming, which are already beginning to disrupt ecosystems and biodiversity in Northern and Southern nations alike.

Both Northern and Southern nations can contribute to reducing these impacts through multilateral environmental agreements, and by improving the efficiency of travel infrastructure, eg. reducing holding times at airports. At a more local scale, new tourism infrastructure and accommodation, especially in rural areas, affects biodiversity through vegetation clearance, fragmentation of animal habitats, noise, pets and pathogens, and water pollution. 
Impacts on biodiversity are particularly severe for large new tourism developments in relatively undisturbed areas, such as those in and around conservation reserves and other protected areas. These developments involve clearing vegetation, major disturbance to fauna through loss of habitat, noise, barriers etc (Buckley 2001a), and marine and freshwater pollution from discharges which include nutrients, metals, pathogens, and toxic chemical compounds such as solvents (Warnken and Buckley 2000).

Even without accommodation and large-scale facilities, nature and adventure tours which are not designed and managed for minimum impact may have considerable impacts on biodiversity and other components of the natural environment. This also applies to specialist tours such as photographic safaris and wildlife watching, which can affect animals through noise, visual and scent disturbance, and by affecting predation and breeding behaviour. Similarly, wildflower tours can affect plant biodiversity if participants collect plants or fruit, introduce weeds or pathogens, or start fires.

Tools to reduce the impacts of tourism on biodiversity, in both North and South, include:

- land zoning and land tenure systems, eg to establish conservation reserves

- land-use planning and development controls, including environmental impact assessment (EIA) to limit development in areas with high biodiversity

- minimal-impact design, construction and operation of tourist facilities (Sweeting et al. 1999).

- park monitoring and management systems including regulations, infrastructure, fees and charges, and education (Buckley 1999b,c)

- tour-operator tools including environmental guidelines (Buckley 1999d, 2001b) and environmental accreditation systems (Font and Buckley 2001) 


\section{Tourism and Conservation Politics in North and South}

In the North, the economic significance of inbound tourists from the South is small compared to that of domestic tourism within the North. Land tenure and property rights, both public and private, are clearly defined. Protected areas, though undersized and underfunded, are well established as a primary tool in conserving biodiversity. In Northern countries, therefore, the major issues are that the growth of Northern tourism in Northern national parks and other protected areas is reducing their effectiveness in conserving Northern biodiversity; but the growth of Northern tourism in public forests and private farmland may be increasing their effectiveness in conserving Northern biodiversity.

In many Southern nations, however, land tenure and land-use planning systems are unstable, development controls weak, and EIA largely absent. In addition, protected areas may be parks only on paper, with inadequate funding for protection and management, and significant impacts from wildlife poaching, a range of small-scale economic activities, and in some areas, large-scale illegal logging. Large areas of land are subject to rapid large-scale degradation either through subsistence activities by expanding local populations, or industrial activities by domestic or international corporations, often with close links to local political power brokers. Reservoirs of biodiversity, of global as well as national significance, are threatened by these activities and lack effective protection in parks.

Potentially at least, Northern tourists can provide a political and social incentive, and the economic means, to conserve Southern biodiversity both in and out of parks. Effectively, nature tourism destinations in Southern countries act as conduits for Northern foreign exchange to enter those countries. Whilst Northern tourism has the potential to help conserve Southern biodiversity, however, this is no guarantee that it will do so in practice. Many other 
conditions must be met for any confidence that the net effects of tourism on biodiversity will be positive. Most importantly:

- countries need effective legal frameworks to ensure that tourism developments are located, designed and operated to minimise environmental impacts, including impacts on biodiversity

- economic gains by tourism based on biodiversity must be used to help conserve that biodiversity, either by direct financial mechanisms or through partnerships between tourism and protected areas, either public or private

- effective political mechanisms and on-ground practices are needed to ensure that higherimpact land uses do not displace both tourism and conservation

- effective mechanisms are needed to ensure that local communities benefit from tourism based on biodiversity, so they have incentives to protect biodiversity and support tourism endeavors.

Under favourable circumstances, Northern tourists visiting biodiversity-based attractions in Southern nations can contribute indirectly to conservation through:

- bringing money into the country, which may be used for national parks and other protected areas and conservation efforts

- providing income and employment for local communities, which may be an incentive to conserve biodiversity

- providing information and interest to Northern tourists, which may potentially influence Northern politics in relation to Southern biodiversity

- contributing to infrastructure in the South, which may lead more Southern domestic tourists to visit the areas concerned, potentially affecting Southern conservation politics

- providing political support for voluntary conservation groups in the South 
There is no guarantee that any of these potential benefits will actually occur, and for each potential benefit there is a corresponding risk of similar or greater magnitude and likelihood. For example, money from Northern tourists may be used largely to buy imports; or it may be used to expand tourism infrastructure in ways with high impacts on biodiversity; or it may be used for purposes unrelated to tourism, such as military expenditure. Similarly, if international tourists from the North open the way for domestic tourists from the South, this may well lead to impacts on biodiversity from large-scale infrastructure development, particularly if domestic tourists are less concerned about conservation than their international counterparts.

There are a number of distinct mechanisms by which Northern tourists may bring money into Southern countries, with different effects on Southern biodiversity:

- direct purchase of goods or services from Southern suppliers

- taxes paid to Southern governments, including those specific to international visitors, those specific to tourism, and general taxes associated with increased economic activity

- fees paid to specific Southern public agencies, such as park entrance, camping and activity fees

- donations from individual Northern tourists or from Northern tour operators, to Southern conservation agencies, communities or voluntary environmental groups

Of these, purchase of goods and services is likely to be the largest component, but least likely to contribute to conservation of biodiversity.

Even if tourism brings money to local communities, this may lead to destruction rather than conservation of biodiversity if:

- local communities don’t control land use and development 
- economic and social impacts of tourism disrupt traditional lifestyles and conservation practices

- tourism increases consumption of local natural resources such as water, firewood, feed for packstock, etc

- lifestyle changes associated with tourism increase demand for cash, and this increases local harvesting of natural resources for sale outside the community

- local residents begin to collect local plants and animals, including rare or endangered species, to sell to tourists as souvenirs, arts and crafts, medicines, etc.

Much of the money may leave the country immediately, for purchase of imports: so-called economic leakage. Where local residents are relatively impoverished, are recent immigrants to the area, or have no tradition of conservation, any additional income is likely to be used in ways which damage biodiversity rather than the reverse. In some destinations, tourism can produce a local economic boom leading to uncontrolled high-impact private development; high resource consumption; waste generation beyond the capacity of local waste treatment disposal systems if any; and land clearance and harvesting with major impacts on biodiversity. In addition, infrastructure built for tourism may be used for illegal collection of endangered plant and animal species. All of these, incidentally, have occurred in the North as well as the South.

Similarly, Southern governments may see Northern tourists attracted by Southern biodiversity as a convenient source of tax revenue, but there is no guarantee that they will use that revenue for conservation. Such taxes include: visa fees; arrivals, departures and "airport improvement” taxes; bed taxes; tourist sales and service taxes; differential prices charged for foreigners by government-owned enterprises such as airlines and hotels; differential user fees charged for foreigners to visit national parks; specialist taxes for particular activities, such as 
heliskiing in India; and licence fees and per capita fees for commercial tour operators (Buckley et al 2001 a,b, Lindberg and Halpenny 2001).

The indirect contributions outlined above are weak and uncertain. If Southern biodiversity is to remain available as a Northern tourism attraction, therefore, the Northern tourism industry probably needs to take an active role in helping to conserve it. Mechanisms include:

- voluntary contributions to parks agencies, e.g. for rangers or equipment

- $\quad$ assistance in monitoring environmental impacts and illegal uses in parks

- alliances with environmental non-government agencies to lobby Southern governments, both to establish conservation areas and to control high-impact industries

- assisting Southern governments in establishing and collecting visitor fees to be used in conservation

- buying private land for tourism and conservation

- debt-for-nature swaps where tourism companies provide funds and non-government organisation negotiate land purchases

\section{Continental Patterns and Case Studies}

The various links between tourism and biodiversity differ in relative significance between continents. Some of the more characteristic features are summarised below, with reference to individual case studies.

In Europe, the significance of biodiversity for tourism is well recognized, and there are multilateral efforts to reduce the environmental impacts of the tourism sector and improve its contribution to conservation (Font and Buckley 2001). Several of these involve national parks agencies, and some include Russia as well as Europe. European nations, particularly 
the Germanic and Scandinavian nations, have been at the forefront of many improvements in environmental management, for the tourism industry as well as other sectors; and tourists originating from these nations are particularly strong supporters of environmental initiatives, internationally as well as domestically.

In subsaharan Africa, biodiversity has long been a major attraction for Northern tourists, with a particular focus on the so-called Big Five and other large mammals in the game parks of the east and south. Other well-known biodiversity-based tourist attractions include the mountain gorillas of Uganda, Rwanda and Zaire; the peculiar plant lifeforms of the east African mountains and the southwestern deserts; the world-famous wildflowers of the temperate southwest; and the spectacular bird life of areas such as the Rift Valley. In addition to internationally-renowned publicly-owned national parks such as the Kruger and Serengeti, there are a number of privately-owned game parks in subsaharan Africa which have successfully rehabilitated and restocked former ranchland, and now operate as conservation reserves and up market wildlife tourism destinations. The greatest concentration of these is in the Sabi Sands area adjacent to Kruger National Park in South Africa. Examples include Sabi Sabi Private Game Reserve, and Ngala and Londolozi owned by Conservation Corporation Africa (CCA). Both CCA and Sabi Sabi have received international recognition for the highest standards of tourist services, as well as for their environmental work. Though small compared to Kruger National Park, which is 2 million hectares in area, they are still substantial reserves, 14000ha each for Londolozi and for Ngala and 8000ha for Sabi Sabi. CCA owns a total of 20 private game lodges and reserves in subsaharan Africa, of which 5 are in South Africa. Details of ownership and land tenure, and the involvement of local communities and protected-area trusts, differ between the various private game reserves; but the overall strategies are similar (Buckley and Sommer 2000). Meanwhile, the publicly 
owned Kruger National Park is also seeking private operators to run its visitor and tourist facilities, leaving parks staff to focus on conservation management (Stoddard 2000).

A slightly different model applies in the KwaZulu-Natal Nature Conservation Service (KZN NCS). KZN NCS, a public agency, has established over 200 conservation agreements with individual landholders in the KwaZulu-Natal province. Whilst most of these landholders continue farming, they also protect wildlife, and many run small-scale wildlife tourism operations. KZN NCS sells them wildlife raised on public reserves, and operates community-development and conservation-donor funds. Over $\$ 7$ million has been donated to local communities, and about 10,000 large mammals, including endangered species, are moved to private parks each year, earning KZN NCS over US\$2 million since 1997 (Buckley and Sommer 2000).

In a private reserve, the prices paid by guests have to cover the full costs of managing the reserve, as well as the guest lodge. Since the larger carnivores need large territories, even the larger private reserves can only support a few individuals of each. For example, in the Sabi Sands area, individual animals may move from one reserve to another, and between the private reserves and Kruger National Park. To ensure that guests see wildlife, therefore, guest numbers must be small. Prices are therefore necessarily high, and guests therefore expect a high level of service, which raises prices even further. These private game reserves and lodges, therefore, are only economically viable as exclusive upmarket destinations, available only to relatively wealthy travelers. This brings in significant flows of Northern cash, with a substantial proportion used directly for conserving Southern biodiversity, since wildlife, and particularly the larger game species, are the primary tourist attraction which keeps the entire business operational. Indeed, the economic significance of the wildlife is clear from the prices paid at wildlife auctions, such as those held by KZN NCS breeding 
programmes. In June 2001, for example, 6 individual black rhino sold for US\$68500 each (Stoddard 2001).

In recent years, these private reserves have also come under heavy political pressure associated with population growth around their borders. Even though the land is privately owned, local villages want to use it for subsistence agriculture. For political survival, the private game lodges therefore need to show that they can provide employment for more local families through operation as a game reserve than would be possible through subsistence farming. Conservation Corporation Africa, for example, established a Rural Investment Fund to support local community projects. This has now been expanded as The Africa Foundation, including other private game reserves. Many of these reserves have also helped to establish small-scale business in local villages as well as providing direct employment in their lodges. Such approaches are particularly significant where lodge employees, though nationals of the country concerned, are not from the immediate vicinity of the reserve. The significance of this strategy is demonstrated by a recent political change in northern Zimbabwe, where an 11,000 hectare section of Gonarezhou National Park - the size of an entire private game reserve - has been thrown open to small-scale settlement by local villages and their cattle (Anon 2001).

There are also private landholdings used for conservation and tourism in South America, but most of these are far smaller than in subsaharan Africa, typically only a few hundred hectares or less. Many of these are in tropical or subtropical rainforest environments, so even a small area may support high biodiversity, sufficient to serve as a tourist attraction. They contribute to biodiversity conservation economically, politically, and by supporting research on endangered species. As with many of the private reserves in Africa, most of them are probably too small to continue supporting viable plant and animal communities if 
surrounding lands were cleared, e.g., for agriculture. In the drier environments such as Brazil's Pantanal, and cool temperate southern Chile and Argentina, the past decade has seen large increases in the number of visitors to publicly owned national parks.

In North America, both the USA and Canada have longstanding systems of parks, forests and other public lands. Historically, the US government has also subsidized clearance and drainage by private landholders. Currently, there are two particularly critical public policy issues in regard to tourism and biodiversity in North America. The first is the management of high-impact recreational activities in national parks, including motorised users, overflights, and horsepackers. The second is the changing management of other public lands, notably forests but also rangeland, from low-yield high-impact uses such as logging, to higher-yield lower-impact tourism (Watson 2001).

Conflicts over the management of national parks for conservation cf recreation, for public recreation cf commercial tourism, and for different types of recreational use are commonplace throughout the developed world, but particularly intense in North America because of high visitor numbers and a historical tradition of high-impact outdoor recreation. Canada, for example, recently replaced its federal national parks legislation with a new Act which sets the maintenance of ecological integrity as the overriding purpose and management goal of the parks. Current problems are exemplified in areas such as the Greater Yellowstone Region, a regional ecosystem centered on Yellowstone National Park, the oldest park in the US system. The region is highly significant for the conservation of large mammals such as buffalo, bear, wolf and antelope, but also contains large areas of land owned by ranchers who are highly antagonistic to wildlife, and numerous small towns which support a thriving tourism industry and are major targets for so-called amenity migration (Achora and O’Leary 2000, Lichtman 2001, Johnson 2001), leading into large and rapid increases in real estate 
prices. Within Yellowstone National Park itself, the principal management conflict is due to winter use by recreational snowmobilers. Throughout much of the park's area, snowmobile noise is a major component of the soundscape; and at tourist icons such as the major geysers, snowmobile noise is continuous (O’Brien 2001). On average, snowmobiles cause 60 times more air pollution than cars, and over $70 \%$ of air pollution in Yellowstone is currently due to snowmobiles (O’Brien 2001). Finally, snowmobiles drive the park’s large mammals, notably bison, out of the park boundaries into surrounding ranchlands, where in a world-class example of government ineptitude, they are shot by the US Department of Agriculture on behalf of local ranchers. Snowmobile use in Yellowstone National Park has now been the subject of political campaigning for a number of years, with conservation organizations and the Parks Service attempting to limit use, and motorized-recreation groups, backed by equipment manufacturers, attempting to extend it. After several years of delay, the former Clinton Administration finally approved a park plan to control snowmobiles, but too late for it to come into effect; and the incoming Bush Administration reversed that decision. As of Jan 2002, the plan was the subject of litigation.

Lands managed by the US Forest Service (USFS), and to a lesser extent its Canadian counterparts, have been used for recreation for many decades. Significant areas of USFS lands, typically the areas without commercial loggable timber, are designated as wilderness and used extensively for backcountry hiking and ski touring. Forest roads and trails outside wilderness areas are used for recreation by four-wheel drive vehicles in summer and oversnow vehicles in winter. And perhaps most significant in economic terms, many of the large ski resorts of the American west are on land leased from the USFS. The significance of public forests in conserving biodiversity, and their importance for tourism, were made clear during the intense public controversy over logging in critical habitat for the endangered Spotted Owl in the Pacific Northwest some years ago. A subsequent review revealed that 
tourism and recreation on USFS land is worth 30 times more than logging. Reflecting this economic reality, the Chief of the USFS during the Clinton Administration began to implement reforms which favoured tourism over timber production. With the start of the Bush Administration, however, the Chief was replaced, and it is not clear whether his reforms will proceed.

As noted earlier, the nations of Asia defy any simple separation into North and South. There are significant biodiversity-based tourism attractions, ranging from the snow leopards and mountain wildflowers of the Himalayas to the tigers of the Terai and Amur, and the rainforests and orang-utan of southeast Asia. There have been significant impacts of tourism on biodiversity, often caused by local entrepreneurs meeting new market demands in areas without effective environment regulation. The best-known example is deforestation in areas of Nepal, through collection of firewood to supply the numerous small-scale tea houses and guest houses which cater to international trekkers. Such secondary impacts may occur even where tourism has been promoted specifically as an aid to the conservation of particular species, as in the panda reserves of southern China (Hesse 2001).

At a regional scale, however, the impacts of tourism on biodiversity pale into insignificance compared to habitat destruction by other sectors, notably agriculture and forestry. In the heavily populated and densely settled areas of India, China, and southeast Asia, continuing expansion and intensification of small-scale agriculture places increasing pressure on the few remaining areas with relatively undisturbed ecosystems. Rainforest ecosystems throughout southeast Asia have been logged extensively, often by corporations based in the richer Asia nations such as Japan. There is now also extensive logging even in the smaller Indo-Pacific island nations such as the Solomons, often by corporations based in countries such as Malaysia. In addition, large areas have been cleared for intensive cash-crop agriculture, 
notably oil palm plantations, and this is continuing. Finally, remaining biodiverse areas such as northwest Vietnam are subject to extensive poaching of endangered animal species to supply the market for so-called traditional Asian medicines (Buckley 1999e).

If Asian nations are to benefit from global growth in nature tourism, the first imperative is to protect their native plants and animals from destructive impacts such as those outlined above. If tourism from Europe and North America can provide the economic and political means and incentives, it will have made a significant contribution to conserving Asian biodiversity. Note that currently, however, nature tourism is only a very small component of the tourism marketing strategies of most Asian nations. Historically, they have focused on history and culture, and in some areas, shopping for duty-free manufactured goods. More recently, many areas are being repackaged as adventure travel destinations, but with a focus on outdoor recreation activities rather than the natural environment (Buckley 2000b).

Because of broader social factors as outlined above, parks and conservation agencies and environmental groups in Asian nations face particular difficulties in their efforts to conserve biodiversity. A number of Asian nations have prepared national ecotourism strategies, but these have come under severe criticisms (Pleumarom 2001). There are many individual tourism operations which have helped to protect biodiversity as well as profiting from it, but these are perhaps the exception rather than the rule. Of course, this pattern is by no means restricted to Asia.

Whilst geographically closest to Asia, the Australian continent is politically closest to North America, and many of the current issues described for the USA also apply. The principal differences are that: national parks and public forests in Australia are largely under the jurisdiction of state rather than federal government; there is no national wilderness 
designation; and whilst public forests are used extensively for private recreation, their use for commercial tourist facilities lags well behind North America. With one or two notable exceptions such as Earth Sanctuaries Ltd (Buckley and Sommer 2000), there are few examples where private land has been purchased and rehabilitated for tourism and biodiversity conservation.

\section{Conclusions}

The Northern tourism industry, along with most of the tourism sector worldwide, relies heavily on Southern as well as Northern biodiversity. It stands to gain more than other industry sectors if biodiversity is protected, and it stands to lose more than other industry sectors if biodiversity is lost. The tourism industry is taking steps to reduce its impacts on biodiversity through improved environmental management, but this alone will not be enough, since other industry sectors may also have major impacts, and since tourism pressures on protected areas continue to grow faster than impacts can be reduced. It is therefore critical for the tourism industry to take an active role in land-use planning and allocation. This includes tourism on private land. Most important, however, are strategic alliances between tourism and conservation interests, to lobby governments to reallocate currently unprotected public lands to tourism and conservation rather than other industry sectors.

\section{References}

Achana, F.T. and O’Leary, J.T. 2000. The transboundary relationship between national parks and adjacent communities. In Machlis, G.E. and Field, D.R. (eds), National Parks and Rural Development in Practice and Policy in the United States, 67-87. Island Press, Washington DC. 
Anon, 2001. Land reform hits Zimbabwean national park. Reuters News Service, 14 May 2001.

Buckley, R.C. 1999a. Tourism and biodiversity: land-use, planning and impact assessment. Journal of Tourism Studies 10 (2): 47-56.

Buckley, R.C. 1999b. Tools and indicators for managing tourism in parks. Annals of Tourism Research 26: 207-210.

Buckley, R.C. 1999c. Carrying capacity: an ecological perspective. Annals of Tourism Research 26: 705-708.

Buckley, R.C. 1999d. Green Guide to White Water: Best-Practice Environmental Management for Whitewater and Raft Kayak Tours. CRC Tourism, Gold Coast, Australia.

Buckley, R.C. 1999e. Planning for a National Ecotourism Strategy in Vietnam. In Pham, L.P. et al (eds.), Development of a National Ecotourism Strategy for Vietnam, 39-45. ITDR \& IUCN Vietnam, Hanoi.

Buckley, R.C. 2000a. NEAT Trends: current issues in nature, eco and adventure tourism. International Journal of Tourism Research 2: 437-444.

Buckley, R.C. 2000b. Regulatory and voluntary frameworks for sustainable tourism development in small islands. In Varma, H. (ed.), WTO-UNEP International Conference on Island Tourism in the Asia and the Pacific, 46-64. WTO, Madrid.

Buckley, R.C. 2001a. Environmental impacts of ecotourism. In Weaver, D. (ed.). The Encyclopedia of Ecotourism, 379-394. CABI, Wallingford.

Buckley, R.C. 2001b. Green Guide for 4WD Tours: Best-Practice Environmental Management for 4WD and Off-road Tours. CRC Tourism, Gold Coast, Australia.

Buckley, R.C. and Sommer, M. 2000. Tourism in Protected Areas: Partnerships in Principle \& Practice. CRC Tourism, Gold Coast. 
Buckley, R.C., Witting, N. and Guest, M. 2001a. Managing People in Australian Parks. 1. Visitor Entrance and Camping Fees. CRC Tourism, Gold Coast.

Buckley, R.C., Witting, N. and Guest, M. 2001b. Managing People in Australian Parks. 2. Commercial Operations Management. CRC Tourism, Gold Coast.

Ceballos-Lascurain, H. 2001. Integrating Biodiversity into the Tourism Sector: Best Practice Guidelines. Report to UNEP/UNDP/GEF Biodiversity Planning Support Programme. PICE, Tlalpan Mexico

Font, X and Buckley, R.C. (eds) 2001. Tourism Ecolabelling. CAB International, Oxford.

Gakahu, C.G. (ed.) 1992. Tourist Attitudes and Use Impacts in Maasai Mara National Reserve. Wildlife Conservation International, Nairobi.

Green, R. J., and Higginbottom, K. 2000. The effects of non-consumptive wildlife tourism on free-ranging wildlife: a review. Pacific Conservation Biology 6:183-97.

Hesse, K. 2001. Loving pandas to death. Newsweek, 8 Mar 01, 85.

Honey, M. 1999. Ecotourism and Sustainable Development: Who Owns Paradise? Island Press, Washington D.C.

Hundloe, T. and Hamilton, C. 1997. Koalas and Tourism: an Economic Evaluation. The Australia Institute, Canberra.

Johnson, J., Maxwell, B. and Aspinall, R. 2001. Moving Nearer to Heaven: Growth and Change in the Greater Yellowstone Region, USA. In Buckley, R.C. (ed.), Abstracts, Fenner Conference on Nature Tourism and the Environment, 20. Australian Academy of Science, CRC Tourism and Griffith University, Gold Coast.

Lichtman, P. 2001. Amenity migrants and their impact on use. In Taylor, L. (ed.), Human Use Management in Mountain Areas. The Banff Centre, Banff (in press).

Lindberg, K. and Halpenny, E. 2001. Protected Area Visitor Fees: Country Review. The International Ecotourism Society, Burlington VT.

O’Brien, S. 2001. Is noise drowning out logic? The Denver Post, 23 May 01. 
Pleumarom, A. 1999. Ecotourism: an Ecological and Economic Trap for Third World Countries. Third World Network, Penang. www.twnside.org.sq/title/cbd

Stoddard, E. 2000. South Africa's national parks woo private sector. Reuters News Service, 27 Nov 2000.

Stoddard, E. 2001. Rhinos break records at South Africa wildlife sales. Reuters News Service, 25 June 2001.

Sweeting, J., Bruner, A. and Rosenfield, A. 1999. The Green Host Effect. Sustainable Approaches to Large-Scale Tourism and Resort Development in Natural Areas. Conservation International, Washington DC.

Warnken, J. and Buckley, R.C. 2000. Monitoring diffuse impacts: Australian tourism developments. Environmental Management 25: 453-461.

Watson, A. 2001. Marketing and public lands in the US: the potential for focus on relationships instead of transactions. In: Buckley, R.C. (ed.), Abstracts, Fenner Conference on Nature Tourism and the Environment, 18. Australian Academy of Science, CRC Tourism and Griffith University, Gold Coast. 